\title{
Bacteroides capillus Kornman and Holt and Bacteroides pentosaceus Shah and Collins, Later Synonyms of Bacteroides buccae Holdeman et al.
}

\author{
J. L. JOHNSON AND LILLIAN V. HOLDEMAN*
}

Department of Anaerobic Microbiology, Virginia Polytechnic Institute and State University, Blacksburg, Virginia 24061

\begin{abstract}
The type strain of Bacteroides pentosaceus Shah and Collins and the type strain of Bacteroides buccae Holdeman et al. have more than $\mathbf{8 0 \%}$ deoxyribonucleic acid homology with the type strain of Bacteroides capillus Kornman and Holt, and therefore the three names are subjective synonyms. Since B. buccae Holdeman et al. was the first validly published name applied to this taxon, $B$. capillus and $B$. pentosaceus are later synonyms of $B$, buccae.
\end{abstract}

Bacterioides capillus Kornman and Holt 1982, $266(3,5)$, Bacteroides pentosaceus Shah and Collins 1982, $266(3,7)$, and Bacteroides buccae Holdeman et al. 1982, 128 (2) are extremely similar phenotypically. The major published difference among these species is liquefaction of gelatin by the type strain and 14 of 18 strains of $B$. buccae and no liquefaction of gelatin by the type strain and two other strains of $B$. capillus (5) and the type strain and two other strains of $B$. pentosaceus (7). However, we found that the type strains of $B$. capillus and $B$. pentosaceus liquefied prereduced peptone-yeast extract-12\% gelatin (1).

The S1 nuclease method (4) was used to determine the levels of deoxyribonucleic acid homology among the type strains of the species. B. buccae strain VPI D3A-6 ${ }^{\mathrm{T}}$ (parent strain of strain ATCC $33374^{\mathrm{T}}$ ) (T = type strain) was from our culture collection. B. capillus ATCC $33690^{\mathrm{T}}$ was from the American Type Culture Collection, Rockville, Md., and $B$. pentosaceus NCDO $2353^{\mathrm{T}}$ was from the National Collection of Dairy Organisms, Reading, England.

Our results (Table 1) indicate that the type strains have more than $80 \%$ deoxyribonucleic acid homology and are the same species. $B$. buccae is the first validly published name,

TABLE 1. Levels of DNA homology among B. buccae, $B$. capillus, and $B$. pentosaceus

\begin{tabular}{|c|c|c|}
\hline \multirow{2}{*}{ Strain } & \multicolumn{2}{|c|}{$\begin{array}{l}\text { \% Homology with reference DNA } \\
\text { from: }\end{array}$} \\
\hline & $\begin{array}{l}\text { B. buccea } \\
\text { VPI D3A-6 }\end{array}$ & $\begin{array}{l}\text { B. capillus } \\
\text { ATCC } 33690^{\mathrm{T}}\end{array}$ \\
\hline B. buccae VPI D3A-6 & $(100)^{a}$ & 82 \\
\hline $\begin{array}{l}\text { B. capillus ATCC } \\
33690^{\mathrm{T}}\end{array}$ & 87 & $(100)^{a}$ \\
\hline $\begin{array}{l}\text { B. pentosaceus NCDO } \\
2353^{\mathrm{T}}\end{array}$ & $\mathrm{NT}^{b}$ & 87 \\
\hline
\end{tabular}

a. Value normalized to $100 \%$.

${ }^{b}$ NT, Not tested. by page priority (6), since the names $B$. capillus and $B$. pentosaceus both were validated in list no. 8 on page 266 of the International Journal of Systematic Bacteriology volume 32 and $B$. buccae was described on page 128 of the same issue. Therefore, $B$. capillus Kornman and Holt and $B$. pentosaceus Shah and Collins are later synonyms of $B$. buccae Holdeman et al.

The technical assistance of Carol Phelps is gratefully acknowledged.

This work was supported by project 2025790 from the Commonwealth of Virginia.

\section{LITERATURE CITED}

1. Holdeman, L. V., E. P. Cato, and W. E. C. Moore (ed.). 1977. Anaerobe laboratory manual. Department of Anaerobic Microbiology, Virginia Polytechnic Institute and State University, Blacksburg.

2. Holdeman, L. V., W. E. C. Moore, P. J. Churn, and J. L. Johnson. 1982. Bacteroides oris and Bacteroides buccae, new species from human periodontitis and other human infections. Int. J. Syst. Bacteriol. 32:125-131.

3. International Journal of Systematic Bacteriology. 1982. Validation of the publication of new names and new combinations previously effectively published outside the IJSB. List no. 8. Int. J. Syst. Bacteriol. 32:266-268.

4. Johnson, J. L. 1981. Genetic characterization, p. 450-472. In P. Gerhardt (ed.), Manual of methods for general microbiology. American Society for Microbiology, Washington, D.C.

5. Kornman, K. S., and S. C. Holt. 1981. Physiological and ultrastructural characterization of a new Bacteroides species (Bacteroides capillus) isolated from severe localized periodontitis. J. Periodontal Res. 16:543-555.

6. Lapage, S. P., P. H. A. Sneath, E. F. Lessel, V. B. D. Skerman, H. P. R. Seeliger, and W. A. Clark (ed.). 1975. International code of nomenclature of bacteria. 1975 Revision. American Society for Microbiology, Washington, D.C.

7. Shah, H. N., and M. D. Collins. 1981. Bacteroides buccalis, sp. nov., Bacteroides denticola, sp. nov., and Bacteroides pentosaceus, sp. nov., new species of the genus Bacteroides from the oral cavity. Zentralbl. Bakteriol. Parasitenkd. Infektionskr. Hyg. Abt. 1 Orig. Reihe C 2:235-241.

\footnotetext{
* Corresponding author.
} 